\title{
PELAKSANAAN KONSELING AWAL PADA KONSELOR SEKOLAH MENENGAH PERTAMA
}

\author{
Yuline \\ Bimbingan dan Konseling, Universitas Tanjungpura \\ Jalan Prof. Dr. H. Hadari Nawawi, Bansir Laut, Pontianak, Kalimantan Barat \\ e-mail: yulinesuwarto@gmail.com
}

\begin{tabular}{|c|c|c|c|c|c|}
\hline $\begin{array}{l}\text { Submitted } \\
2021-08-03\end{array}$ & $\begin{array}{c}\text { Accepted } \\
2021-11-21\end{array}$ & $\begin{array}{l}\text { Published } \\
\text { 2021-12-07 }\end{array}$ & open 2 ACCEss & 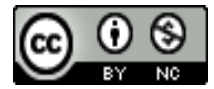 & anvinta 3 \\
\hline
\end{tabular}

\begin{abstract}
Abstrak
Penelitian bertujuan mendeskripsikan pelaksanaan konseling awal pada konselor dalam melaksanakan konseling individual. Metode penelitian yang digunakan adalah deskriptif dengan bentuk penelitian survei. Alat pengumpul data menggunakan angket dan wawancara. Analisis data menggunakan rumus persentase dan analisis rasional. Populasi penelitian sebanyak 35 konselor dari 23 SMP negeri dan 2 SMP swasta di Kabupaten Kubu Raya. Sampel penelitian menggunakan teknik sampling total sehingga yang menjadi sampel penelitian adalah seluruh populasi. Berdasarkan hasil penelitian, disimpulkan bahwa secara umum konselor dalam melaksanakan konseling awal berada pada kategori sedang dengan rincian: indikator menyiapkan diri konselor, mengobservasi, dan mendengarkan berada pada kategori baik; indikator menyiapkan diri konseli dan melayani secara pribadi berada pada kategori sedang; dan indikator menyiapkan konteks berada pada kategori rendah. Hasil penelitian juga menunjukkan bahwa konselor kurang memahami keterampilan konseling, keterbatasan ruang konseling, pengembangan diri konselor, dan keterbatasan literatur.
\end{abstract}

Kata Kunci: konseli; konseling awal; konselor.

\begin{abstract}
The research aimed to describe the implementation of initial counseling to counselors in carrying out individual counseling. The research method used descriptive in the form of survey research. Data collection tools used questionnaires and interviews. Data analysis used the percentage formula and rational analysis. The research population was 35 counselors from 23 public junior high schools and 2 private junior high schools in Kubu Raya Regency. The research sample used a total sampling technique so that the research sample was the entire population. Based on the results of the research, it was concluded that in general the counselors in carrying out initial counseling were in the moderate category with details: indicators of preparing the counselor, observing, and listening were in the good category; indicators of preparing the counselee and serving personally are in the medium category; and indicators of setting up context are in the low category. The results also showed that counselors do not understand counseling skills, limited counseling space, counselor self-development, and limited literature.
\end{abstract}

Keywords: counselee; initial counselling; counselor. 


\section{PENDAHULUAN}

Pelaksanaan konseling pada sekolah menengah pertama (SMP) di Kabupaten Kubu Raya masih belum maksimal. Hal tersebut diperoleh dari data hasil pertemuan dengan guru Bimbingan Konseling (BK) SMP di Kabupaten Kubu Raya yang tergabung dalam Musyawarah Guru Bimbingan Konseling (MGBK) pada saat mengikuti pelatihan keterampilan konseling. Permasalahan yang guru alami adalah belum mampu melaksanakan konseling individual sesuai dengan teori yang seharusnya.

Konseling adalah proses pemberian bantuan yang dilakukan melalui wawancara konseling oleh seorang ahli (konselor) kepada individu yang sedang mengalami sesuatu masalah (konseli) yang bermuara pada teratasinya masalah yang dihadapi oleh konseli (Prayitno \& Amti, 2015). Konseling sebagai profesi yang bersifat membantu memiliki landasan ilmu dan teknologi serta wilayah praktik yang jelas dan dapat dibedakan dengan profesi-profesi lain yang bersifat membantu (Wibowo, 2018). Mengingat konseling adalah kegiatan yang profesional, maka konselor harus benar-benar ahli dalam bidangnya karena melaksanakan konseling merupakan kegiatan unik yang melibatkan kemampuan berpikir kematangan dan kepekaan emosional serta menuntut perubahan perilaku dari seorang konselor. Keunikan tersebut disebabkan oleh keberadaan konseling sebagai ilmu juga sebagai kiat. Penguasaan teknik dasar konseling perlu ditempuh melalui latihan keterampilan yang ada secara sistematis dan prosedural, baik melalui adegan permainan peran maupun self-instruction. Hasil latihan kemudian diinternalisasikan ke pribadi konselor sehingga keterampilan yang telah dipelajari dapat digunakan pada saat melakukan konseling.

Hasil wawancara dengan knselor SMP negeri dan swasta pada kegiatan MGBK di SMPN 2 Sungai Raya Kabupaten Kabu Raya, diperoleh informasi bahwa konselor dalam melaksanakan konseling masih kurang mampu menggali penyebab munculnya masalah. Konselor hanya fokus pada kekurangan yang ada dalam diri konseli. Konselor seharusnya menunjukkan kelebihan yang dimiliki konseli sehingga konseli tidak merasa dipojokkan. Konselor dalam proses konseling biasanya hanya memberikan nasihat sehingga konseli kurang mendapat 
Edukasi: Jurnal Pendidikan, Volume 19 Nomor 2 Tahun 2021

Pelaksanaan Konseling Awal pada Konselor Sekolah Menengah Pertama

Yuline

Halaman 245-259

solusi sesuai dengan permasalahan yang sedang dialaminya. Hal tersebut karena konselor belum sepenuhnya menggunakan berbagai keterampilan konseling.

Konseling individual tidak hanya dibutuhkan siswa yang rendah prestasinya, akan tetapi yang memiliki prestasi tinggi juga memerlukannya. Penelitian tentang self-esteem dan pelayanan bimbingan dan konseling yang dibutuhkan siswa kelas akselerasi hasilnya menjelaskan bahwa salah satu layanan yang dibutuhkan adalah konseling individual (Yendi et al., 2015). Penelitian yang mengambil sampel dari beberapa SMA di Amerika mendapatkan hasil 89\% siswa SMP yang melanjutkan pendidikan ke SMA adalah siswa yang hadir melakukan kegiatan konseling secara tatap muka dengan konselor (Velez, 2016). Apabila dikaji lebih mendalam, hasil penelitian mengisyaratkan bahwa konseling dibutuhkan oleh semua siswa, baik yang memiliki kemampuan tinggi maupun rendah.

Salah satu faktor penunjang keberhasilan konseling adalah mampu melaksanakan hubungan konseling awal. Namun, tidak semua konselor memiliki keterampilan tersebut. Hasil penelitian yang mengungkapkan bahwa perolehan skor dengan kualifikasi cukup terhadap beberapa keterampilan komunikasi pada konselor disebabkan karena terbatasnya pemahaman konselor terkait keterampilan yang dimaksudkan (Widodo, 2012). Selain menguasai keterampilan komunikasi konseling, konselor juga harus memiliki kemampuan hubungan konseling awal yang tidak terlepas adanya keterampilan konseling. Konseling sangat memerlukan hubungan yang hangat layaknya persahabatan dan pengertian dari konselor kepada konseli sehingga tumbuh penerimaan, hubungan, dan rasa percaya tanpa syarat dan pamrih. Kegiatan tahap konseling awal harus ada perbedaan dan tidak langsung memasuki tahap menasihati tapi memperhatikan kerangka-kerangka agar sesi konseling berjalan baik (Gregg, 2015).

Diperlukan hubungan konseling awal yang mencakup aspek menyiapkan konteks, diri konselor, konseli, melayani secara pribadi, mengobservasi, dan mendengarkan demi terwujudnya konseling yang efektif (Abimanyu \& Manrihu, 2009). Menyiapkan konteks merupakan kegiatan konselor dalam menyiapkan ruangan konseling yang memungkinkan konseli merasa aman, tenang, rileks, dan nyaman. Konselor juga perlu mempersiapkan dirinya baik fisik maupun psikis. 
Sebelum melakukan konseling konselor perlu memikat konseli, memberikan informasi tentang etika konseling, memberikan motivasi agar mau terbuka dan aktif pada saat pelaksanaan konseling. Mengobservasi dan mendengarkan sangat perlu dilakukan konselor karena dapat membantu mengungkap kondisi konseli.

Kenyataannya apa yang sudah dipaparkan masih belum dilaksanakan secara maksimal oleh konselor dalam melaksanakan hubungan konseling awal. Hal tesebut karena terbatasnya pengetahuan dan keterampilan yang dimiliki konselor sehingga kurang mampu melakukan kegiatan tersebut. Berdasarkan pada uraian tersebut, maka tujuan penelitian adalah untuk mendeskripsikan pelaksanaan konseling awal pada konselor SMP di Kabupaten Kubu Raya yang tergabung dalam MGBK.

\section{METODE}

Metode penelitian yang digunakan adalah deskriptif dengan bentuk penelitian survei. Variabel penelitiannya adalah pelaksanaaan hubungan konseling awal pada konselor SMP Kabupaten Kubu Raya. Indikatornya yaitu menyiapkan konteks, menyiapkan diri konselor, menyiapkan diri konseli, melayani, mengobservasi, mendengarkan secara akurat, dan masalah yang dihadapi konselor. Populasi penelitian terdiri dari konselor SMP Negeri 1 hingga SMP Negeri 23, dan dua konselor SMP swasta di Kabupaten Kubu Raya yang tergabung dalam wadah MGBK yang berjumlah 35 orang.

Berhubung populasi hanya berjumlah 35 orang, maka teknik sampling yang digunakan adalah sampling total. Hal tersebut berarti yang menjadi sampel penelitian adalah seluruh populasi penelitian. Teknik komunikasi langsung dan tidak langsung digunakan untuk mengumpulkan data dengan alat pengumpul datanya angket dan wawancara. Angket digunakan untuk memperoleh data submasalah sampai enam. Wawancara menggali permasalahan yang dihadapi konselor dalam pelaksanaan konseling. Kisi-kisi angket terlihat di Tabel 1 dan kisikisi pedoman wawancara terlihat di Tabel 2. 
Tabel 1 Kisi-Kisi Angket

\begin{tabular}{clc}
\hline Variabel & \multicolumn{1}{c}{ Indikator } & Jumlah Butir \\
\hline & Menyiapkan konteks & 10 \\
& Menyiapkan diri konselor & 11 \\
Hubungan & Menyiapkan konseli untuk konseling & 10 \\
konseling awal & Attending & 6 \\
& Mengobservasi konseli & 9 \\
& Mendengarkan & 14 \\
\hline
\end{tabular}

Tabel 2 Kisi-Kisi Pedoman Wawancara

\begin{tabular}{cl}
\hline Aspek & \multicolumn{1}{c}{ Indikator } \\
\hline \multirow{3}{*}{$\begin{array}{c}\text { Masalah yang dihadapi } \\
\text { konselor }\end{array}$} & $\begin{array}{l}\text { Konselor kurang memahami keterampilan konseling; } \\
\text { Keterbatasan ruangan konseling; } \\
\text { Pengembangan diri konselor; } \\
\text { Keterbatasan literatur. }\end{array}$ \\
\hline
\end{tabular}

Analisis data menggunakan rumus persentase (Sudijono, 2014) seperti yang terlihat pada rumus (1).

$$
P=\frac{F}{N} X 100 \%
$$

Keterangan: $\mathrm{P}$ adalah angka persentase; $\mathrm{F}$ adalah frekuensi yang sedang dicari presentasenya; $\mathrm{N}$ adalah number of case (jumlah frekuensi/responden).

Kualitas hasil perhitungan tersebut dikonsultasikan dengan kategori penilaian hasil angket yang disusun seperti yang terlihat pada Tabel 3.

Tabel 3 Tolok Ukur Pelaksanaan Hubungan Konseling Awal

\begin{tabular}{cc}
\hline Persentase & Kategori \\
\hline $80 \%-100 \%$ & Baik Sekali \\
$70 \%-79 \%$ & Baik \\
$60 \%-69 \%$ & Sedang \\
$50 \%-59 \%$ & Kurang \\
$<50 \%$ & Kurang Sekali \\
\hline
\end{tabular}

\section{HASIL DAN PEMBAHASAN}

Hasil analisis data terhadap pelaksanaan hubungan konseling awal yang dilakukan oleh konselor SMP di Kabupaten Kubu Raya yang tergabung dalam MGBK diperoleh skor sebesar $68 \%$ dengan kategori sedang. Hal tersebut menunjukkan bahwa aspek-aspek yang ada pada hubungan konseling awal baru dilaksanakan $68 \%$, masih ada yang belum dilaksanakan dengan baik. Keberhasilan 
konselor dalam membantu konseli tidak terlepas dari hubungan yang kuat antara konselor dan konseli yang dapat membuat konseli merasa nyaman saat melakukan strategi monitoring diri (Baker et al., 2012). Apabila konselor dan konseli dalam proses konseling ada perasaan yang kurang nyaman, segera diungkapkan sehingga hubungan semakin dapat ditingkatkan dan pembelajaran yang diperoleh dapat diterapkan dalam kehidupan.

Hasil penelitian terhadap konselor SMP di Kubu Raya dalam melaksanakan hubungan konseling awal belum sepenuhnya menggunakan berbagai keterampilan yang ada dalam konseling. Hal tersebut sesuai dengan hasil penelitian terdahulu yang menunjukkan bahwa hasil pengukuran aspek kognitif keterampilan dasar konseling tentang penguasaan konsep attending, questioning, observing, dan responding masih belum memuaskan (Bustaman, 2016). Konselor dalam melakukan layanan konseling belum sepenuhnya menggunakan keterampilan konseling. Hal yang sama terjadi terhadap hasil penelitian yang peneliti lakukan, yaitu konselor belum mampu menggunakan berbagai keterampilan konseling. Oleh karenanya, perlu adanya pelatihan bagi para konselor untuk meningkatkan kompetensinya. Konselor yang terampil adalah yang mengetahui atau memahami sejumlah keterampilan tertentu dan mampu mengimplementasikannya dalam proses konseling (Tohirin, 2013).

\section{Menyiapkan Konteks}

Hasil penelitian tentang aspek menyiapan konteks memperoleh skor 56\% dengan kategori rendah. Keadaan tersebut menggambarkan bahwa hanya $56 \%$ konselor yang melakukan penataan ruangan tempat melakukan konseling. Adapun yang perlu ditata dalam menyiapkan konteks, yaitu pengaturan dekorasi ruangan, pengaturan tempat duduk, jarak tempat duduk, letak tempat duduk konseli, dan ruangan konseling (Abimanyu \& Manhiru, 2009).

Mendekorasi ruangan dapat memengaruhi psikologis diri. Salah satu faktor penting yang pengaruhnya besar terhadap proses konseling sehingga memengaruhi hasilnya adalah tempat dilakukannya konseling (Gunarsa, 2010). Tempat duduk disusun rapi supaya konseli merasa tenang. Tempat duduk harus diatur sedemikian 
Edukasi: Jurnal Pendidikan, Volume 19 Nomor 2 Tahun 2021

Pelaksanaan Konseling Awal pada Konselor Sekolah Menengah Pertama

Yuline

Halaman 245-259

rupa sehingga konseli tidak merasa terancam atau terganggu oleh konselor (Gunarsa, 2010). Penataan tempat duduk yang baik, konseli tidak merasa seperti sedang diadili. Jarak tempat duduk konselor dan konseli dapat memengaruhi keterbukaan konseli dalam mengemukakan masalahnya. Jarak yang terlalu dekat kurang baik karena dapat membuat konseli kaku dan risih, begitu juga sebaliknya, jarak yang terlalu jauh dapat membuat hubungan antara konseli dan konselor kurang akrab.

Letak tempat duduk konseli juga perlu diatur agar pandangan konseli tidak langsung tertuju pada konselor. Sebaiknya tempat duduk konseli menghadap jendela agar dapat melemparkan pandangan ke luar supaya mengurangi rasa kikuknya berhadapan dengan konselor. Ruang konseling juga sangat memengaruhi keterbukaan konseli. Ruangan yang sempit dan pengap karena tidak ada jendela menambah ketidaknyamanan konseli. Proses konseling dibutuhkan berbagai fasilitas ruang Bimbingan Konseling sehingga diri konseli merasa nyaman, senang, dan terbuka (Fatchurahman, 2017).

\section{Menyiapkan Diri Konselor}

Salah satu aspek yang berperan dalam keberhasilan hubungan konseling awal adalah kesiapan diri konselor. Hasil penelitian tentang aspek menyiapkan diri konselor memperoleh skor $74 \%$ dengan kategori baik. Artinya bahwa konselor sudah mampu mempersiapkan diri dengan baik sebelum melaksanakan konseling. Menyiapkan diri konselor yang perlu dilakukan, yaitu perlu mengetahui apakah konseli datang sendiri atau tidak, pengenalan data tentang diri konseli, mengkaji tujuan konseling, dan membuat diri konselor rileks (Carkhuff, 2008). Sebelum melaksanakan konseling, konselor sudah mencari informasi apakah konseli datang ke ruang BK dengan kemauannya sendiri atau ada yang menyuruhnya. Konselor perlu mengenal data tentang diri konseli agar ketika bertemu dengan konseli seolah-olah sudah mengenalnya, jadi suasana pertemuan pertamanya tidak kaku. Selanjutnya konselor mengkaji tujuan konseling untuk menetapkan yang ingin dicapai dalam konseling. Konselor sebelum melakukan konseling mampu bersikap rileks (tidak tegang) jadi dalam menghadapi konseli merasa nyaman. 
Menyiapkan diri konselor tidak bisa dilepaskan dari kemampuan konselor berempati terhadap konseli. Empati merupakan kecenderungan seseorang untuk mampu menempatkan diri dalam pikiran dan perasaan orang lain (Sugiyatno, 2012). Empati merupakan salah satu teknik yang dipercaya dapat meningkatkan efektivitas pelayanan konseling yang diberikan kepada konseli (Handari et al., 2016). Konseling pada dasarnya merupakan bentuk kegiatan komunikasi interpersonal antara konselor dan konseli yang didukung oleh sejumlah teknik dan pendekatan-pendekatan psikologis tertentu seperti salah satunya sikap empati dalam komunikasi (Sugiyatno, 2012). Empati erat hubungannya dengan keterampilan interpersonal karena mengandung kemampuan penggunaan bahasa atau pikiran individu. Namun, tidak semua konselor memiliki keterampilan tersebut. Hasil penelitian tentang keterampilan konseling berbasis metakognisi mengindikasikan bahwa dalam pelaksanaan konseling, konselor belum memperhitungkan keefektifan keterampilan intrapersonal sebagai suatu keterampilan yang terintegrasi dalam diri konselor (Radjah, 2016).

\section{Menyiapkan Diri Konseli}

Menyiapkan diri konseli sebelum melaksanakan konseling merupakan hal yang sangat penting dilakukan konselor. Konseli perlu disiapkan sebelum konseling dilaksanakan agar mengerti apa yang harus dilakukan dalam proses konseling. Hasil penelitian tentang menyiapkan konseli memperoleh skor $65 \%$ dengan kategori sedang. Keadaan tersebut menggambarkan bahwa hanya 65\% konselor yang mempersiapkan konseli untuk melakukan konseling. Konselor dalam mempersiapkan diri konseli dapat dilakukan dengan cara memikat konseli, memberikan informasi tentang konseling, dan mendorong konseli untuk mengambil konseling (Carkhuff, 2008). Konselor mampu memikat konseli dengan cara mengemukakan kelebihan konseli sehingga merasa dihargai. Sikap hormat adalah memperlakukan orang sebagai manusia yang layak dihargai (Geldard, 2015). Memikat konseli bisa juga dilakukan melalui sikap ramah, hangat, dan bersahabat agar konseli merasa lebih rileks serta tidak khawatir akan dipermalukan atas kekurangannya. 
Edukasi: Jurnal Pendidikan, Volume 19 Nomor 2 Tahun 2021

Pelaksanaan Konseling Awal pada Konselor Sekolah Menengah Pertama

Yuline

Halaman 245-259

Konselor memberikan informasi tentang etika konseling yang berisi kode etik konseling yang harus dipatuhi, baik oleh konselor maupun konseli. Konselor memotivasi konseli untuk aktif dalam proses konseling dengan menggunakan berbagai teknik konseling yang dikombinasikan, konseli akan terbuka dan jujur menceritakan permasalahan yang dihadapi secara utuh dan ikut serta dalam pelaksanaan konseling (Handari et al., 2016). Tujuan utama menggunakan keterampilan konseling adalah membantu konseli mengembangkan keterampilan pribadi dan inner strength (kekuatan batin) agar konseli dapat menciptakan kebahagiaan dalam kehidupannya sendiri dan orang lain (Nelson-Jones, 2011).

\section{Melayani (Attanding) secara Pribadi}

Melayani secara pribadi adalah tingkah laku konselor yang menunjukkan pada konseli bahwa konselor benar-benar bersama konseli. Hasil penelitian pada aspek melayani pribadi memperoleh skor $65 \%$ dengan kategori sedang, hal tersebut menunjukkan bahwa hanya $65 \%$ konselor yang mampu menggunakan berbagai keterampilan attending dengan baik. Keterampilan melayani secara pribadi sangat diperlukan adanya sikap yang tulus tanpa pamrih. Sikap menerima orang lain secara tulus mengisyaratkan tidak menghakimi (Geldard, 2015). Melayani secara pribadi berfungsi agar konselor dapat memperlihatkan penampilan attending dalam berbagai situasi hubungan interpersonal secara umum, khususnya dalam relasi konseling dengan konseli (Willis, 2011).

Melayani secara pribadi adalah usaha konselor untuk menempatkan diri sedemikian rupa sehingga dapat memberikan perhatian secara penuh pada konseli. Apabila konseli sedang berbicara, konselor hendaknya mengikuti arah pembicaraan konseli sehingga konselor mampu memberikan dorongan minimal (Carkhuff, 2008). Jika konselor mampu melayani secara pribadi pada saat konseling, maka dapat memengaruhi kepribadian konseli. Adapun kepribadian konseli yang dimaksud, yaitu: (1) Meningkatkan harga diri konseli; (2) Menciptakan suasana aman bagi konseli; dan (3) Memberikan keyakinan konseli bahwa konselor tempat untuk mencurahkan segala isi hati perasaannya (Willis, 2011). Melayani secara pribadi tidak terlepas dari kemampuan berempati yang 
harus dimiliki konselor agar mampu melayani konseli dengan baik. Hasil penelitian terdahulu menunjukkan bahwa teknik modeling efektif meningkatkan empati mahasiswa (Sutanti, 2015). Hasil penelitian tersebut dapat dijadikan masukan bagi calon konselor maupun yang sudah jadi konselor untuk bahan pelatihan meningkatkan kemampuan berempati.

\section{Keterampilan Mengobservasi}

Keterampilan mengobservasi adalah kegiatan konselor melihat langsung keadaan konseli pada saat konseling. Aspek yang perlu diobservasi adalah dimensi fisik, emosional, dan intelek (Carkhuff, 2008). Hasil penelitian tentang aspek mengobservasi memperoleh skor $76 \%$ dengan kategori baik. Artinya bahwa $76 \%$ konselor melakukan observasi terhadap konseli. Keterampilan mengobservasi merupakan ketampilan konseling yang paling dasar. Melalui observasi, konselor dapat mempelajari diri konseli. Hasil penelitian menggambarkan bahwa konselor dalam hubungan konseling awal sudah melakukan observasi dengan baik terhadap konseli. Observasi terhadap konseli perlu dilakukan karena sangat membantu konselor mengungkap keadaan konseli.

\section{Keterampilan Mendengarkan}

Mendengarkan merupakan masukan yang paling sering digunakan dalam konseling. Apa yang diungkapkan konseli dan bagaimana mengungkapkannya adalah gambaran diri konseli dan dunia sekitarnya. Hasil penelitian tentang keterampilan mendengarkan diperoleh skor $72 \%$ dengan kategori baik. Artinya bahwa $72 \%$ konselor mampu mendengarkan apa yang diungkapkan konseli. Hal tersbut menggambarkan bahwa konselor saat mendengarkan sudah mampu menunda penilaian yang dapat menjaga unsur subjektivitas. Konselor yang menjadi pendengar aktif menunjukkan sikap kepedulian kepada konseli (Lianawati, 2017). Keterampilan mendengarkan juga dapat membantu konselor untuk memusatkan isi pembicaraan konseli, mengingat apa yang diekspresikan konseli, serta mampu menemukan tema pokok semua yang sudah dibicarakan. 
Edukasi: Jurnal Pendidikan, Volume 19 Nomor 2 Tahun 2021

Pelaksanaan Konseling Awal pada Konselor Sekolah Menengah Pertama

Yuline

Halaman 245-259

\section{Masalah-Masalah yang Dihadapi Konselor dalam Pelaksanaan Konseling Individu}

Keberhasilan pelaksanaan konseling individu dipengaruhi oleh berbagai faktor, diantaranya dari konselor sendiri dan sarana-prasarana yang mendukung terlaksananya konseling. Faktor yang berasal dari konselor biasanya kurang menguasai pengetahuan dan berbagai keterampilan yang ada dalam konseling, sedangkan dari faktor sarana-prasarana adalah kurang tersedianya fasilitas yang memadai untuk terlaksananya kegiatan konseling dengan baik. Ruangan BK hanyalah ruangan-ruangan parasit yang menumpang pada ruang guru atau ruang tata usaha (Fatchurahman, 2017). Hasil wawancara yang peneliti lakukan pada konselor SMP di Kabupaten Kubu Raya tentang masalah yang dihadapi konselor, yaitu: (1) Kurang memahami pentingnya keterampilan konseling yang seharusnya digunakan dalam pelaksanaan konseling, khususnya pada hubungan konseling awal; (2) Keterbatasan ruangan konseling; (3) Pengembangan diri konselor; dan (4) Keterbatasan literatur- literatur tentang konseling.

\section{Konselor kurang memahami keterampilan konseling}

Keberhasilan konselor dalam melaksanakan konseling salah satu faktor pendukungnya adalah penggunaan keterampilan konseling sesuai dengan konteksnya. Hubungan konseling awal adalah kegiatan yang dilakukan konselor dalam mempersiapkan pelaksanaan konseling. Kegiatan yang perlu dilakukan adalah menyiapkan ruangan untuk konseling, menyiapkan diri konselor, menyiapkan diri konseli, mengobservasi konseli, melayani konseli, dan mendengarkan apa yang sedang diungkapkan oleh konseli. Kegiatan-kegiatan yang ada pada tahapan hubungan konseling awal seharusnya dilakukan oleh konselor. Namun, belum semua konselor SMP yang tergabung dalam MGBK Kabupaten Kubu Raya melakukan kegiatan tersebut. Hal tersebut disebabkan belum semua konselor memahami mengunakan keterampilan konseling. 


\section{Keterbatasan ruangan konseling}

Dibutuhkan ruangan yang memadai saat melakukan konseling. Hal tersebut penting agar konseli merasa aman dan nyaman dalam menjalankan konseling. Faktor penting yang dapat menghambat proses konseling salah satunya adalah tempat konseling dilakukan (Gladding, 2012). Apabila sekolah tidak memiliki ruangan tersendiri untuk melakukan konseling, maka pelaksanaan konseling akan terganggu hingga sulit untuk mencapai tujuan yang ditetapkan. Konselor mengatakan bahwa belum memiliki ruangan konseling secara khusus. Ruangan konseling disatukan dengan ruang kesehatan (P3K) atau perpustakaan. Hal tersebut sesuai dengan hasil penelitian yang menunjukkan hanya 56\% konselor yang memiliki ruangan khusus untuk kegiatan konseling.

\section{Pengembangan diri konselor}

Konselor dapat mengembangkan diri menjadi seorang profesional dengan aktif mengikuti kegiatan yang bersifat ilmiah. Namun, tidak semua konselor memiliki kesempatan tersebut. Hasil wawancara diperoleh informasi bahwa konselor jarang mengikuti kegiatan ilmiah, baik tingkat kabupaten, provinsi ataupun nasional. Hal tersebut karena masih kurang mendapatkan fasilitas dari pihak sekolah. Apabila ada kegiatan berupa seminar, pelatihan, ataupun workshop biasanya mengeluarkan biaya sendiri. Jadi konselor kurang termotivasi mengikuti kegiatan ilmiah yang dapat menghambat pengembangan diri konselor.

\section{Keterbatasan literatur}

Membaca adalah modal utama untuk mendapatkan berbagai macam pengetahuan karena dapat membuka wawasan sehingga pola pikir makin berkembang (Rahmani, 2019; Kurniawati, 2016). Perkembangan zaman yang semakin maju dan teknologi semakin pesat menyebabkan tantangan yang dihadapi semakin kompleks. Konselor dituntut mengikuti perkembangan zaman melalui berbagai cara, salah satunya membiasakan diri membaca literatur terbaru sehingga konselor dapat mengimbangi perkembangan zaman yang semakin kompleks. Namun kenyataannya, budaya membaca para konselor masih rendah. Konselor 
Edukasi: Jurnal Pendidikan, Volume 19 Nomor 2 Tahun 2021

Pelaksanaan Konseling Awal pada Konselor Sekolah Menengah Pertama

Yuline

Halaman 245-259

kurang memiliki literatur konseling terbaru sehingga pemahaman terhadap konseling kurang optimal.

\section{SIMPULAN}

Berdasarkan hasil penelitian, disimpulkan bahwa pelaksanaan konseling awal berada pada kategori sedang, dengan rincian: indikator menyiapkan diri konselor, mengobservasi, dan mendengarkan berada pada kategori baik; indikator menyiapkan diri konseli dan melayani secara pribadi berada pada kategori sedang; dan indikator menyiapkan konteks berada pada kategori rendah. Hasil tersebut menunjukkan bahwa konselor SMP di Kabupaten Kubu Raya yang tergabung dalam MGBK belum mampu melaksanakan konseling awal dengan baik. Hasil penelitian juga menunjukkan bahwa konselor kurang memahami keterampilan konseling, keterbatasan ruangan konseling, pengembangan diri konselor, dan keterbatasan literatur.

\section{DAFTAR PUSTAKA}

Abimanyu, S. \& Manrihu, M. T. (2009). Teknik dan Laboratorium Konseling. Makassar: Badan Penerbit Universitas Negeri Makasar.

Baker, S. B., Tyler, R. E., Lupton-Smith, H. S., Wang, A. B., Allen, A. H., Wapner, K. H., Fleder, S. D., \& Isaac, S. T. (2012). Self-Monitoring as a Counseling Teachnique and an Accountability Strategy dalam https://www.counseling.org/docs/default-source/vistas/self-monitoring-as-acounseling-technique-and-an-accountability-strategy.pdf?sfvrsn=8. Diakses 23 Agustus 2021.

Bustaman, N. (2016). Keterampilan Dasar Konseling: Laporan Tes dan Langkah Berikutnya. Jurnal Suloh, 1(1), 27-35.

Carkhuff, R. R. (2008). The Art of Helping. Ninth Edition. Amherst, MA: Possibilities Publishing, Inc.

Fatchurahman, M. (2017). Problematik Pelaksanaan Konseling Individual. Jurnal Bimbingan dan Konseling Ar-Rahman, 3(2), 25-30. http://dx.doi.org/10.31602/jbkr.v3i2.1160. 
Geldard, K. (2015). Membantu Memecahkan Masalah Orang Lain dengan Teknik Konseling, terjemahan Agung Prihantoro. Yogyakarta: Pustaka Pelajar.

Gladding, T. S. (2012). Konseling Profesi yang Menyeluruh. Edisi Enam. Jakarta: PT Indeks.

Gregg, B. A. (2015). Academic Training in Initial Counseling of Parents of Preschoolers Who Stutter: A Simulated Caregiver Model. Procedia-Social and Behavioral Sciences, 193(2015), 123-130.

Gunarsa, S. D. (2010). Konseling dan Psikoterapi. Jakarta: Libri.

Handari, S., Rosidah, R., \& Eva, E. (2016). Empati Sebagai Pengembangan Konseling untuk Efektivitas Pelayanan Konseling. LENTERA, 18(1), 49-63. https://doi.org/10.21093/lj.v18i1.852.

Kurniawati, T. (2015). Minat Membaca Mahasiswa Program Studi Pendidikan Bahasa Inggris. Edukasi: Jurnal Pendidikan, 13(2), 227-238. http://dx.doi.org/10.31571/edukasi.v13i2.118.

Lianawati, A. (2017). Implementasi Keterampilan Konseling dalam Layanan Konseling Individual. Seminar \& Workshop Nasional Bimbingan dan Konseling: Jambore Konseling 3.

Nelson-Jones, R. (2011). Teori dan Praktik Konseling dan Terapi. Edisi Keempat. Penerjemah H. P. Soetjipto dan S. M. Soetjipto. Yogyakarta: Pustaka Pelajar.

Prayitno \& Amti, E. (2015). Dasar-Dasar Bimbingan Konseling. Jakarta: PT Reneka Cipta.

Radjah, C. L. (2016). Keterampilan Konseling Berbasis Metakognisi. Jurnal Kajian Bimbingan dan Konseling, 1(3), 90-94. http://dx.doi.org/10.17977/um001v1i32016p090.

Rahmani, E. (2019). Analisis Minat Baca Mahasiswa Pendidikan Bahasa Inggris terhadap Artikel Ilmiah. Edukasi: Jurnal Pendidikan, 17(2), 198-211. http://dx.doi.org/10.31571/edukasi.v17i2.1247.

Sudijono, A. (2014). Pengantar Evaluasi Pendidikan. Jakarta: PT Raja Grafindo Persada. 
Edukasi: Jurnal Pendidikan, Volume 19 Nomor 2 Tahun 2021

Pelaksanaan Konseling Awal pada Konselor Sekolah Menengah Pertama

Yuline

Halaman 245-259

Sugiyatno. (2012). Komunikasi Interpersonal yang Empatis Membentuk Kompetensi Konselor Profesional dalam Layanan Konseling. Prosiding Seminar Internasional Bimbingan dan Konseling Universitas Negeri Jogjakarta Tahun 2012.

Sutanti, T. (2015). Efektivitas Teknik Modeling untuk Meningkatkan Empati Mahasiswa Prodi BK Universitas Ahmad Dahlan. Jurnal Kajian Psikologi Pendidikan dan Bimbingan Konseling,1(2),188-198. https://doi.org/ 10.26858/jpkk.v1i2.1906.

Tohirin. (2013). Bimbingan dan Konseling di Sekolah dan Madrasah (Berbasis Integrasi). Edisi Revisi. Jakarta: Rajawali Pers.

Velez, E. D. (2016). How Can High School Counseling Shape Students' Postsecondary Attendance. Exploring the Relationship Between the High School Counseling Contex and Students Subsequent Postsecondary Enrollment dalam https://www.nacacnet.org/globalassets/documents/ publications/research/hsls-phase-iii.pdf. Diakses 23 Agustus 2021.

Wibowo, E. M. (2018). Profesi Konselor Abad 21. Semarang: UNNES Press.

Widodo, B. (2012). Aplikasi Keterampilan Komunikasi Konselor dalam Proses Konseling di SMP Negeri Kota Madiun. Widya Warta: Jurnal Ilmiah Universitas Katolik Widya Mandala Madiun, 36(01), 52-65.

Willis, S. (2011). Konseling Individual Teori dan Praktek. Bandung: Alfabeta.

Yendi, F. M., Syukur, Y., \& Rafsyam, Y. (2015). Self-Esteem dan Pelayanan Bimbingan dan Konseling yang Dibutuhkan Siswa Kelas Akselerasi. Jurnal Konselor UNP, 4(4), 191-195. https://doi.org/10.24036/02015446471-0-00. 